\title{
THE SPENCEVILLE COPPER MINE CLOSURE ${ }^{1}$
}

\author{
William J. Walker², Dan Wanket and Alberto Pujol
}

\begin{abstract}
Spenceville Mine is an abandoned copper mine located in the Sierra Nevada foothills of California. The mine was operated intermittently from the 1880's until 1918. The site was covered with mine tailings and overburden materials. In addition, the central portion of the site was occupied by a flooded open pit, which contained approximately 6 million gallons of acidic water with a $\mathrm{pH}$ averaging 2.5. The U.S Army owned the site from 1941 to 1962, at which time it was transferred to the California Department of Fish and Game (DFG) with the creation of the Spenceville Wildlife Refuge.

The closure plan was approved by the regulatory agencies in early 2001, and mine closure activities began in April 2001. In subsequent months a water treatment plant was constructed and used to treat the pit water. The treated water was then applied to land in the vicinity of the site. The mine waste was excavated, treated with lime, and placed in the dewatered pit. A two foot layer of local soil was placed as cover over the entire site, and a mine-impacted stream was restored to its original channel. In addition to these tasks, closure activities had to address the potential for unexploded ordnances, reclamation of shafts and tunnels in the dewatered pit, and documentation of cultural resources.
\end{abstract}

${ }^{1}$ Oral paper to be presented at the 2016 National Meeting of the American Society of Mining and Reclamation, Spokane, WA, Reclaiming the West, June 4-9, 2016. R.I. Barnhisel (Ed) Published by ASMR; 1305 Weathervane Dr., Champaign, IL 61821.

${ }^{2}$ Walker, William J. Senior Chemist, Sovereign Consulting, Inc., $21024^{\text {th }}$ Ave, Seattle, WA 98121. Alberto Pujol, Vice President and Dan Wanket, Vice President, GEO Consultants, Oakland, CA.

Journal American Society of Mining and Reclamation, 2016 Volume 5, Issue 1 pp 147 - 166 DOI: http://doi.org/10.21000/JASMR16010147 


\section{INTRODUCTION}

\section{Objectives}

The overall purpose of the Spenceville mine closure was to implement a plan that would bring the property back to pre-mining conditions to the extent practical. The plan that was adopted included dewatering the pit and treating the water in a lime neutralization plant, then using the treated water for irrigation of salt tolerant plants. The plan also included treating the mine waste with a liming agent and filling the dewatered pit with the treated mine waste. Once complete the mined area would be contoured back to pre-mining condition and then revegetated.

The project was complicated by the fact that the California Department of Fish and Game required the closure to be implemented and completed in 18 months for various internal reasons. In addition, the pit had to be dewatered and then backfilled with treated mine waste, within a very limited time frame due to groundwater re-filling the pit. As such, the project success would hinge on the ability of the team to complete tasks in well-defined intervals with few, if any, upsets to the schedule.

\section{$\underline{\text { Site Location }}$}

The Spenceville Mine site is located within the California Department of Fish and Game's (DFG) Spenceville Wildlife Refuge in the foothills of the Sierra Nevada Mountain range, about 18 miles southwest of Grass Valley, in Nevada County, California. The mine site is east of Beale Air Force Base (Fig. 1.)

\section{$\underline{\text { Site History }}$}

The mine was called the Well Lode Copper Mine from 1863 through 1865 and closed shortly after the Civil War ended. In 1877 the mine was operated jointly by the Grass Valley Copper Mine and the San Francisco Mining Company. In 1880, the head frame toppled into a vertical shaft and the mine began to operate as an open pit. Eight years later the mine closed. From 1888 through 1897 the Imperial Paint Company and Copper Works leached the tailings for copper cement and also used them as a pigment in the manufacture of paint. In 1897 the Spence Mineral Company purchased the mine proper to manufacture sulfuric acid. Between 1915 and 1917 a fire razed the mine properties and all work there ceased for good (After Wanket, 2002). 


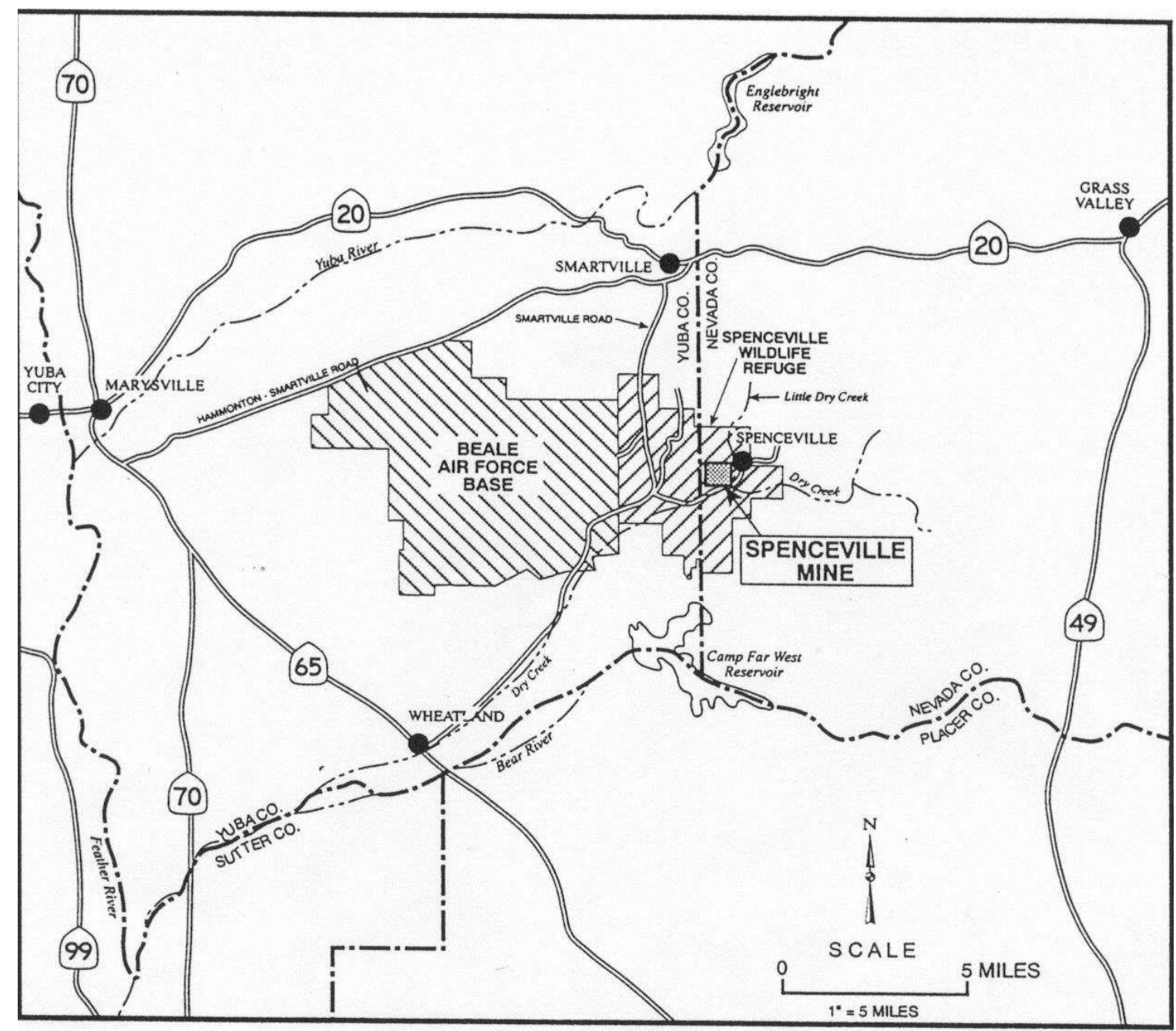

Figure 1. Location of the Spenceville Copper Mine.

In 1962 the Spenceville Wildlife Refuge was created via a land transfer to the California Department of Fish and Game (DFG). The Spenceville Mine site and old town of Spenceville are within the Spenceville Wildlife Refuge boundaries. In April 1987, the California Regional Water Quality Control Board (RWQCB), Central Valley Region, asserted regulatory jurisdiction over the site by notifying DFG that the mine was regulated under the Toxic Pits Cleanup Act (TPCA) of 1984. TPCA required that all surface impoundments containing hazardous wastes be closed or modified so they were no longer hazards (After Wanket, 2002).

\section{$\underline{\text { Site Description }}$}

The Spenceville Mine site area covers approximately 9.5 acres and is bounded on the east and south by Little Dry Creek and Dry Creek, respectively. The mine site is located at altitudes ranging 
from 300 to 500 feet. The mine site is characterized by the large pit lake (Fig. 2) which contained approximately 6 million gallons of acid mine water $(\mathrm{pH} \sim 2.5)$ originating from sulfide mineral oxidation within the tailings and waste rock piles surrounding the pit. The pit's surface area was approximately one-half acre, and depth ranged from 60 to 90 feet. Surrounding the pit on the west and north were piles of waste rock and roasted ore waste (Fig. 3). Little Dry Creek flows south and is approximately 80 feet southeast of the mine pit. It joins Dry Creek approximately 400 feet south of the mine pit (Fig. 4).

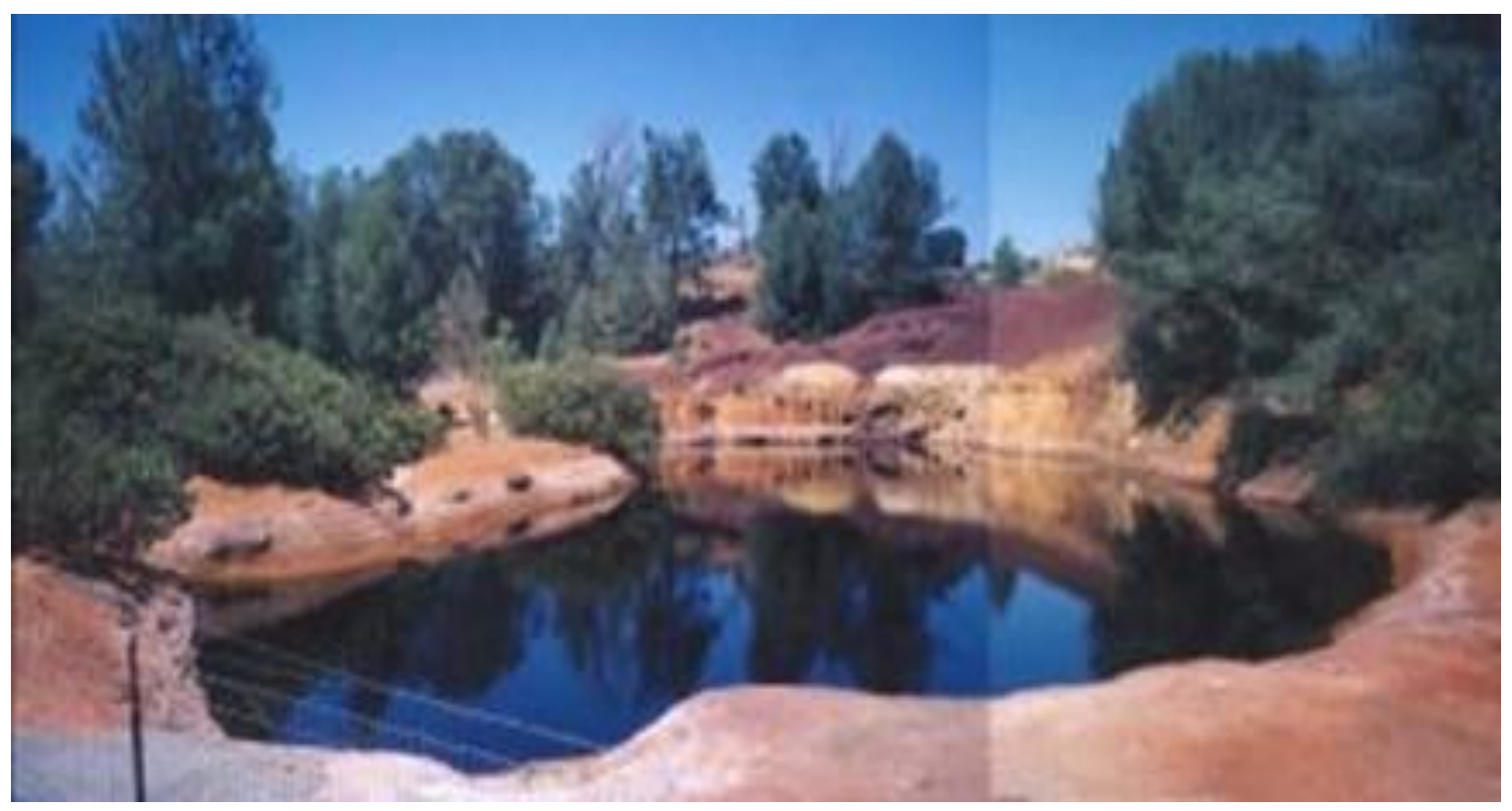

Figure 2. Spenceville Copper Mine pit lake.

The pit lake water had elevated concentrations of sulfate, $\mathrm{Fe}, \mathrm{Cu}$, and $\mathrm{Zn}$. Periodic surface water runoff and ground water seepage discharged into the open pit lake. The pit lake in turn discharged low $\mathrm{pH}$ waters that were high in $\mathrm{Cu}, \mathrm{Zn}, \mathrm{Fe}$, and $\mathrm{Al}$ to adjacent Little Dry Creek. The concentration of $\mathrm{Cu}$ and $\mathrm{Zn}$ in the discharge was sufficient to be detrimental to aquatic habitat. In addition, the proximity of the acidic-open-pit lake to a public access road created a public safety hazard. 
JASMR, 2016 Volume 5 Issue 1

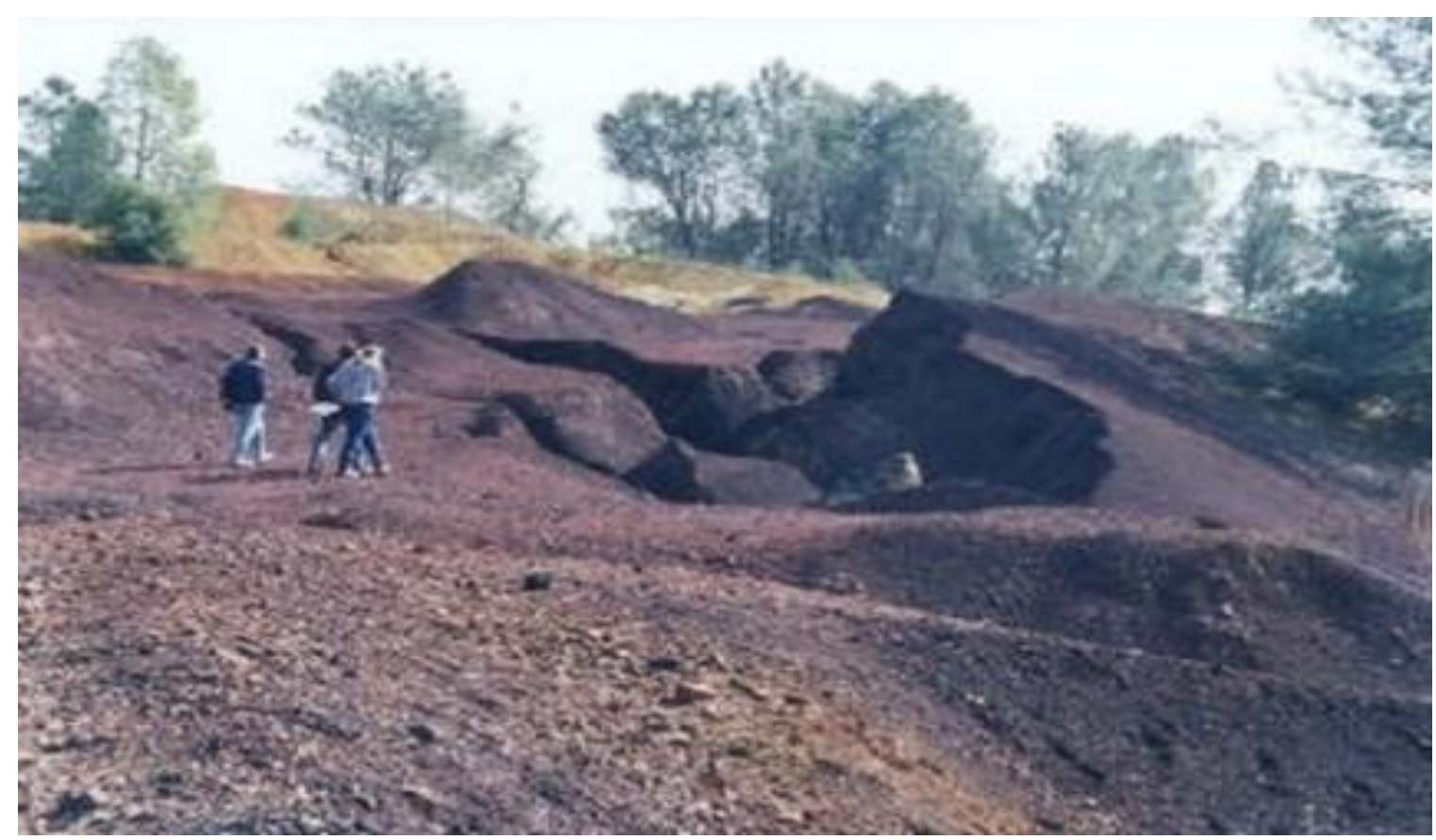

Figure 3. Mine waste and roasted ore.

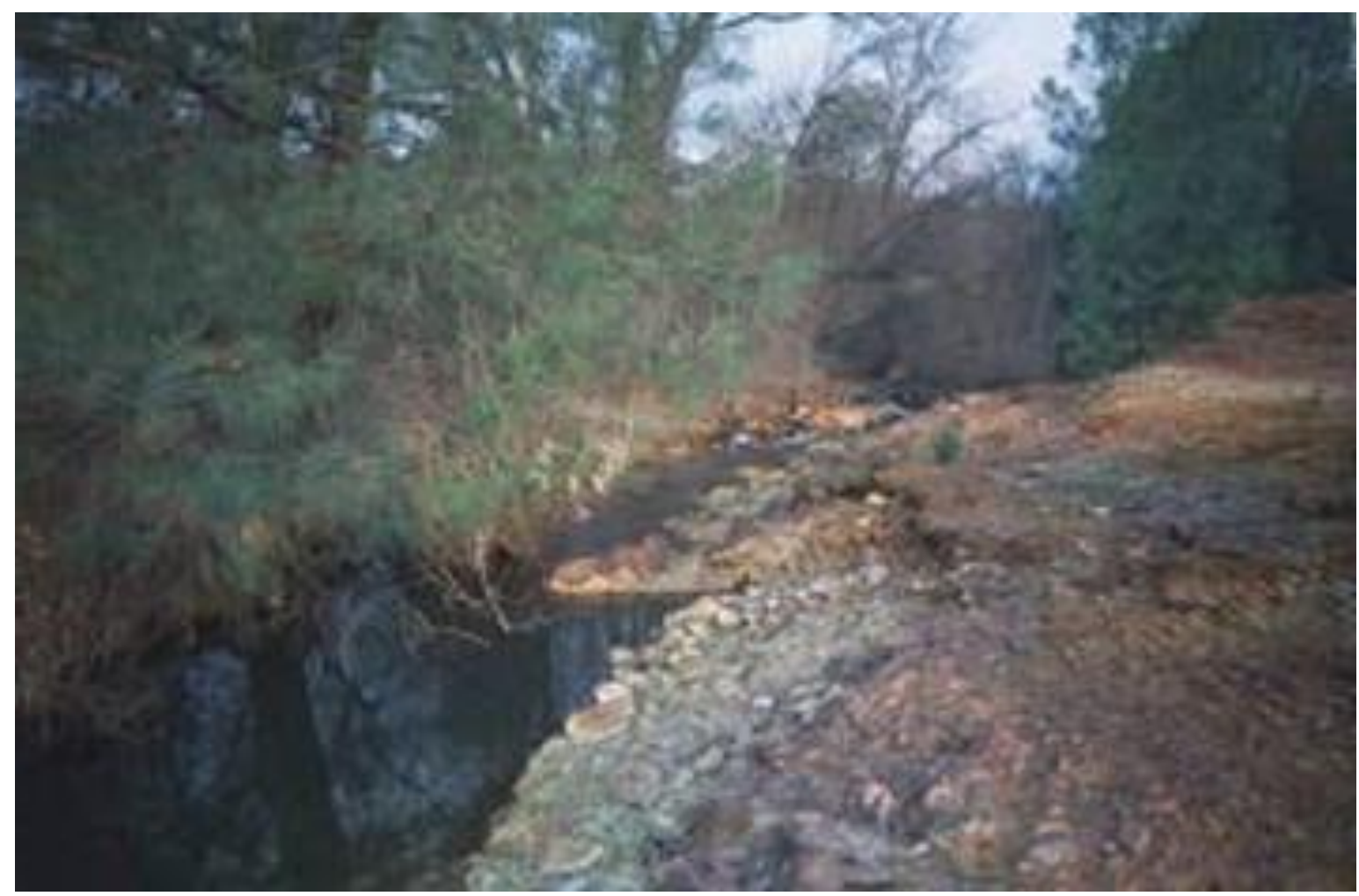

Figure 4. Little Dry Creek just south of the mine pit lake. 


\section{MINE CLOSURE IMPLEMENTATION}

The mine closure team was comprised of Walker and Associates, Inc. (Project Management and Water and Soil Quality), GEI Consultants (Engineering), and CRE, Inc. (Construction). Prior to closure, various alternative remedial approaches were developed for treating the mine water, disposing of the mine waste, and filling the pit. Two mine closure plans were proposed for fine screening. While both alternatives included dewatering the pit and treating the water in a lime neutralization plant, one alternative consisted of treating the mine waste with a liming agent and filling the pit with the treated mine waste. The other alternative did not treat the mine waste, but consisted of placing the untreated tailings into an engineered landfill, to be located near the mine site and above the 100-year flood plain. Because of the mineralized condition of the rock adjacent to the pit, this second alternative assumed that the pit would need to be filled with limestone rock. Based on the fine screening evaluation, the alternative that included treatment of the mine waste and placing the treated mine waste in the pit was selected for implementation.

Reclamation activities began in April 2001. Initial reclamation activities included securing the site perimeter with fencing, installing temporary erosion and sediment controls such as silt fences and limestone berms, construction of access roads, and site grading for laydown areas and treatment plant facilities. The major activities associated with the mine reclamation are presented below.

\section{$\underline{\text { Pit Dewatering and Water Treatment }}$}

The purpose of the water treatment plant at the Spenceville Mine was to treat the 6 million gallons of acid mine drainage in the pit so that backfilling with neutralized tailings and waste rock could be accomplished before groundwater seeped back in. Treated water from the plant was discharged as irrigation water to a nearby sunflower field (10 acres) resulting in minimal impact to the area soils and vegetation.

Low $\mathrm{pH}$ and high acidity in the water was created by the oxidation of pyrite and other copper sulfide minerals in the underground workings along with the oxidation of $\mathrm{Cu}$ and $\mathrm{Zn}$ sulfide minerals in ore and waste piles. At the cessation of mining (early 1900's) the pit filled with water and became acidic and metal rich due to the exposed oxidizing pyrite and $\mathrm{Cu} / \mathrm{Zn}$ sulfide minerals. 
Pit water chemistry was determined by California Fish and Game in 1988 and again prior to closure by Walker and Associates in 2000. Results of the water quality analysis revealed the following features:

- The chemistry for the two sampling events is shown in Table 1. While there are some differences in chemistry between the two sampling events, the results are in general fairly similar (Fig. 5).

- The pit water was highly stratified. The top 0 to $15 \mathrm{ft}$ was relatively dilute compared to the deeper portions of the pit water.

- Meteoric water and runoff tend to both mix and dilute only the upper few feet of the pit. Mixing and turnover with the lower 30 to 60 feet of water does not occur.

- Acidity, metals, and most of the major cations and anions all increased in concentration with depth. Sulfate increased from about $1000 \mathrm{mg} / \mathrm{L}$ in the top $3 \mathrm{ft}$ to almost $15000 \mathrm{mg} / \mathrm{L}$ near the bottom of the pit. Dissolved Fe (total) ranged from $100 \mathrm{mg} / \mathrm{L}$ in the surface water to about $4000 \mathrm{mg} / \mathrm{L}$ at the pit bottom.

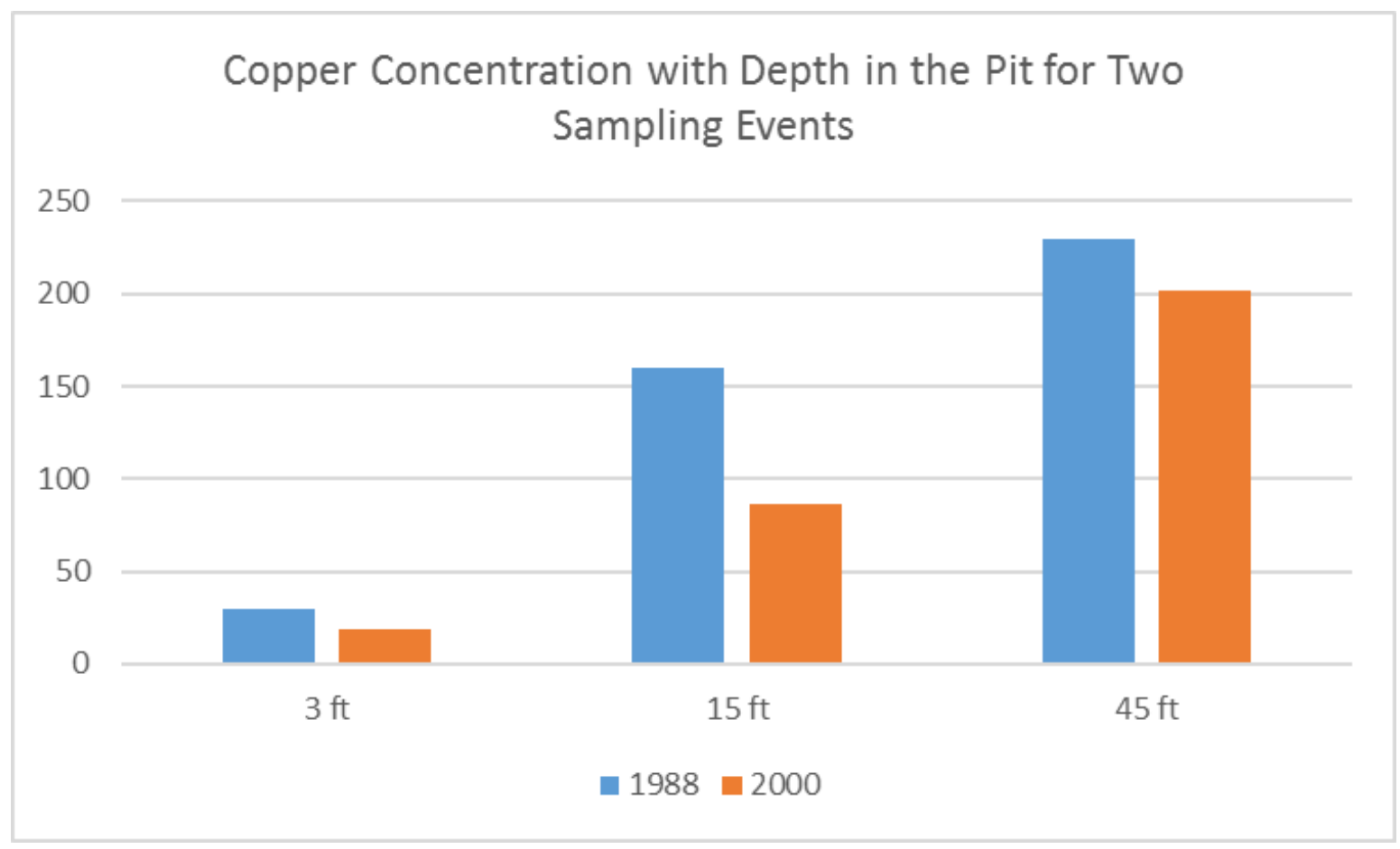

- $\quad$ Figure 5. Copper concentrations measured during two differrent timeframes. 
JASMR, 2016 Volume 5 Issue 1

Table 1. Pit water chemistry in 1988 (DFG) and 2000 (WAI)

\begin{tabular}{|c|c|c|c|c|c|c|c|}
\hline & & $\begin{array}{c}\text { 3' depth } \\
\text { (1988) }\end{array}$ & $\begin{array}{c}15 \text { ' depth } \\
\text { (1988) }\end{array}$ & $\begin{array}{c}\text { 45' depth } \\
\text { (1988) }\end{array}$ & $\begin{array}{c}3 \text { ' depth } \\
(2000)\end{array}$ & $\begin{array}{c}15^{\prime} \text { depth } \\
(2000)\end{array}$ & $\begin{array}{c}45 \text { ' depth } \\
\text { (2000) }\end{array}$ \\
\hline $\mathrm{pH}$ & [std units] & 2.7 & 2.2 & 2.6 & 2.8 & 2.4 & 2.7 \\
\hline Alk. & {$[\mathrm{mg} / \mathrm{L}]$} & 0 & 0 & 0 & 0 & 0 & 0 \\
\hline Acid. & {$[\mathrm{mg} / \mathrm{L}]$} & 750 & 3,700 & 11,000 & 590 & 2,640 & 9,120 \\
\hline $\mathrm{SO}_{4}$ & {$[\mathrm{mg} / \mathrm{L}]$} & 1,300 & 4,800 & 14,000 & 742 & 3,800 & 12,100 \\
\hline $\mathrm{Cl}$ & {$[\mathrm{mg} / \mathrm{L}]$} & 2 & $<4$ & $<4$ & $<40$ & $<40$ & $<40$ \\
\hline $\mathrm{Na}$ & {$[\mathrm{mg} / \mathrm{L}]$} & 19 & 30 & 55 & 10.1 & 23.5 & 41.2 \\
\hline $\mathrm{K}$ & {$[\mathrm{mg} / \mathrm{L}]$} & nd & 8.6 & 29 & 1.2 & 0.8 & 0.25 \\
\hline $\mathrm{Ca}$ & {$[\mathrm{mg} / \mathrm{L}]$} & 120 & 220 & 430 & 106 & 221 & 365 \\
\hline $\mathrm{Mg}$ & {$[\mathrm{mg} / \mathrm{L}]$} & 75 & 200 & 530 & 20 & 175 & 494 \\
\hline $\mathrm{Cd}$ & {$[\mathrm{mg} / \mathrm{L}]$} & 0.09 & 0.15 & 0.31 & 0.029 & 0.058 & 0.240 \\
\hline $\mathrm{Cu}$ & {$[\mathrm{mg} / \mathrm{L}]$} & 30 & 160 & 230 & 18.9 & 86 & 202 \\
\hline $\mathrm{Pb}$ & {$[\mathrm{mg} / \mathrm{L}]$} & nd & nd & nd & 0.009 & 0.023 & $<0.003$ \\
\hline $\mathrm{Zn}$ & {$[\mathrm{mg} / \mathrm{L}]$} & 20 & 45 & 220 & 9.80 & 22.7 & 145 \\
\hline As & {$[\mathrm{mg} / \mathrm{L}]$} & na & na & na & 0.0054 & 0.024 & 0.0037 \\
\hline $\mathrm{Ni}$ & {$[\mathrm{mg} / \mathrm{L}]$} & na & na & na & $<0.100$ & 0.234 & 0.884 \\
\hline $\mathrm{Fe}$ (total) & {$[\mathrm{mg} / \mathrm{L}]$} & 120 & 910 & 4900 & na & na & 3860 \\
\hline
\end{tabular}

nd $=$ not determined, na $=$ not analyzed

The primary chemicals requiring removal in the pit water were $\mathrm{Cu}, \mathrm{Zn}, \mathrm{Fe}$, and acidity. A temporary, but conventional, lime treatment plant was constructed to raise $\mathrm{pH}$ to about 7.5 , neutralize acidity, and remove metals from solution via precipitation as hydroxides and carbonates. Water from the pit was conveyed at about $180 \mathrm{gpm}$ via three pumps placed in the pit at 10, 25, and 45 feet below the water surface, respectively. The use of multiple pumps allowed blending of water to maintain consistent influent chemistry. Figures 6 and 7 show the pit in two stages of dewatering. 
JASMR, 2016 Volume 5 Issue 1

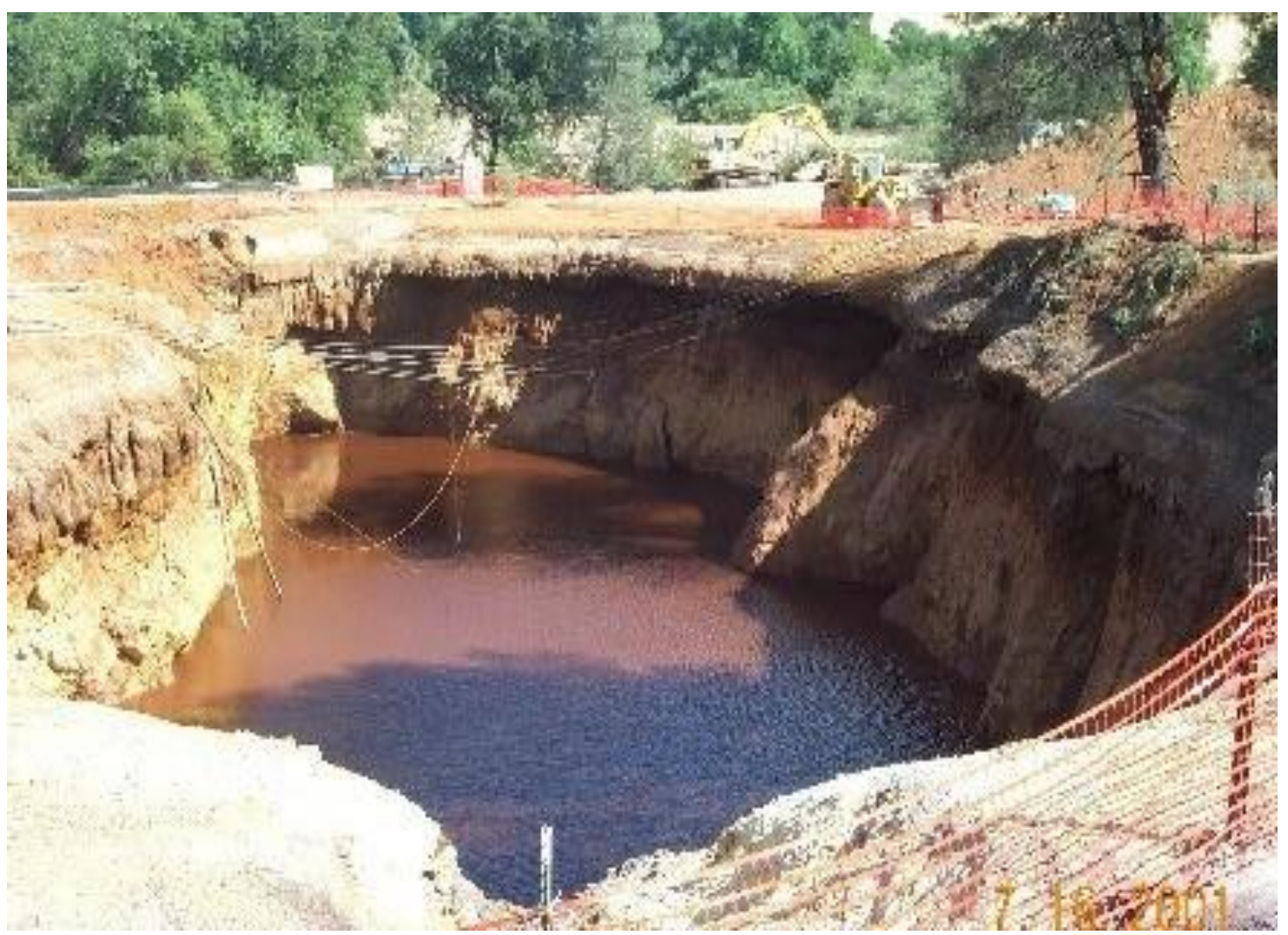

Figure 6. Mine pit dewatering, July 16, 2001

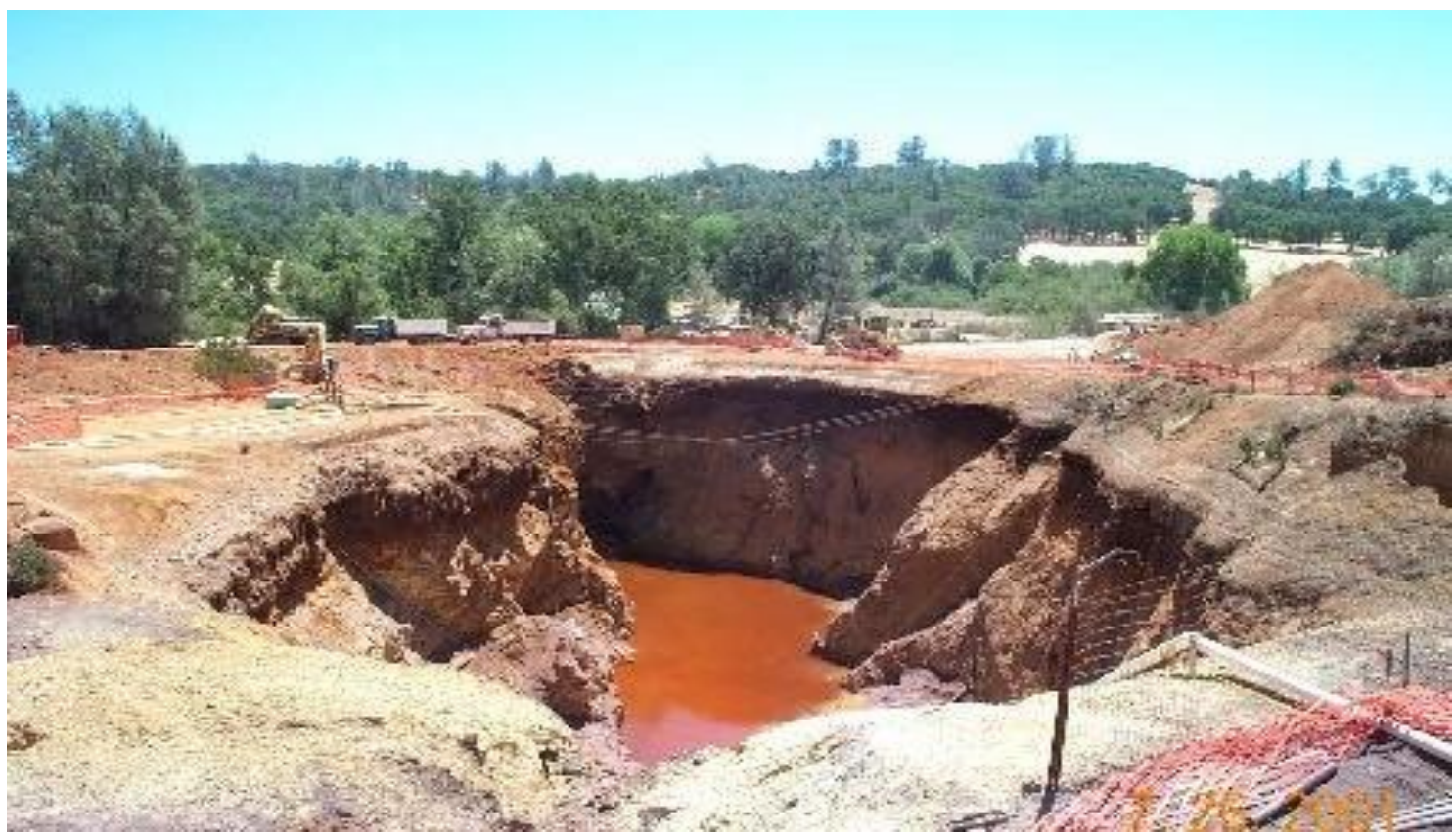

Figure 7. Mine pit dewatering, August 27, 2001. 
Once in the plant, gravity flow was used to forward processed water from one treatment unit to the next. In the first main reactor, a compressed airline was used to aerate influent water to ensure that any $\mathrm{Fe}^{+2}$ in the pit water was converted to $\mathrm{Fe}^{+3}$, which is amenable to removal via neutralization. Neutralization in this reactor was achieved by the addition of hydrated lime slurry $\left(30 \% \mathrm{Ca}(\mathrm{OH})_{2}\right)$ to pit water in the well-mixed aerated tank. A pH-controlled lime pump was used to maintain tank $\mathrm{pH}$ at approximately 7.5 , which is the titration endpoint that provides minimum solubility of the metals of concern.

Effluent from the main reactor tanks drained into a 1,000-gallon flocculation/coagulation tank. The coagulation tank effluent drained into an upright 5,000-gallon clarifier with removable lamella plates. In the clarifier, metal hydroxide solids and gypsum settled to the bottom and were pumped over to the filter press. Clean, treated water overflowed out the top and was collected in a $\mathrm{pH}$ adjustment tank and then to a 500,000-gallon holding pond before being pumped to the land application area for discharge as irrigation water. Figure 8 shows the treatment plant during operation.

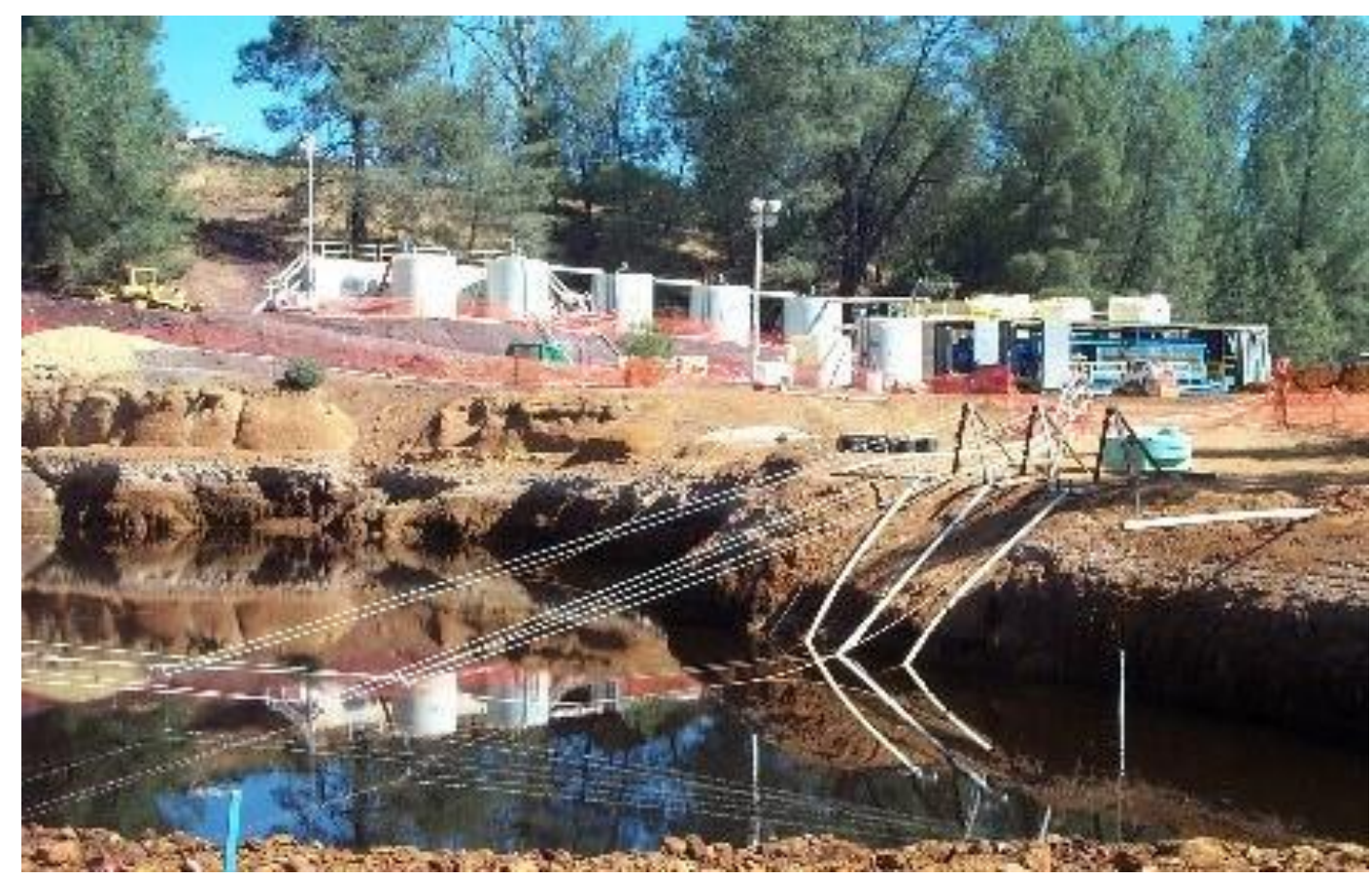

Figure 8.Treatment plant and pit dewatering. 
Sludge from the clarifier was pumped into a solids-holding tank. Sludge slurry was pumped to two parallel filter presses, where it was dewatered. Effluent from the filter press was routed to the treated-water-holding tank and dewatered sludge was transported to a holding area on site before eventually being hauled to a licensed hazardous waste facility.

\section{Treatment Plant Effluent Water Quality}

Typical effluent water quality deteremined from twice-weekly sampling and anaysis is presented in Table 2. Removal of the main constituents of concern ( $\mathrm{Fe}, \mathrm{Cu}$, and $\mathrm{Zn}$ ) as well as other trace constituents (such as lead) was approximately 99\%, as shown in Table 2.

\section{Mine Waste Excavation, Treatment, and Placement in Pit}

Approximately 70,000 cubic yards (cu yd) of tailings were excavated and mixed with sugar beet lime to raise the $\mathrm{pH}$. The treated tailings were placed in the pit and compacted to reduce their volume and compressibility.

Mine waste, waste rock, and tailings at the site were separated into several broad groups which included:

- Hematite tailings: red-purple-black roasted ore material composed of iron oxides, other metals and low sulfur contents.

- Jarosite piles: piles of yellowish mine overburden material composed of potassium iron hydrous sulfate.

- Disturbed native materials: the areas mapped as containing "disturbed native materials" included three benches (flat areas) where various mine facilities were once located and the area to the east and south of the mine pit.

- Pit bottom sediments: mainly hematite mine waste that eroded from the hematite deposits and was transported into the pit by storm runoff. 
JASMR, 2016 Volume 5 Issue 1

Table 2. Treatment plant performance (average of 27 measurements).

\begin{tabular}{llcccc}
\hline & & $\begin{array}{c}\text { Initial composite pit } \\
\text { water }\end{array}$ & Treated effluent & \% Removal & $\begin{array}{c}\text { Target Effluent } \\
\text { Water Quality }\end{array}$ \\
\hline $\mathrm{pH}$ & {$[\mathrm{std}$ units $]$} & 2.54 & 7.0 & - & 6.5 to 9 \\
Sulfate & {$[\mathrm{mg} / \mathrm{L}]$} & 5,547 & 3,100 & - & 3,100 \\
Calcium & {$[\mathrm{mg} / \mathrm{L}]$} & 231 & 1,000 & - & 1,000 \\
Cadmium & {$[\mathrm{mg} / \mathrm{L}]$} & 0.11 & $<0.05$ & - & 0.005 \\
Copper & {$[\mathrm{mg} / \mathrm{L}]$} & 121 & $<0.1$ & $>99.9$ & 0.2 \\
Iron & {$[\mathrm{mg} / \mathrm{L}]$} & 853 & 9.3 & 98.9 & $<10$ \\
Magnesium & {$[\mathrm{mg} / \mathrm{L}]$} & 229 & 170 & 0 & $<200$ \\
Manganese & {$[\mathrm{mg} / \mathrm{L}]$} & 12 & 4.1 & 65.8 & $<5$ \\
Nickel & {$[\mathrm{mg} / \mathrm{L}]$} & 1.0 & $<0.1$ & $>90.0$ & 0.1 \\
Lead & {$[\mathrm{mg} / \mathrm{L}]$} & 0.3 & $<0.005$ & $>98.3$ & 0.015 \\
Zinc & {$[\mathrm{mg} / \mathrm{L}]$} & 38 & 0.2 & No effect & $<10$ \\
Nitrate & {$[\mathrm{mg} / \mathrm{L}]$} & 0.6 & 0.57 & No effect & $<10$ \\
Chloride & {$[\mathrm{mg} / \mathrm{L}]$} & 4 & 3.8 & & 2.0 \\
\hline
\end{tabular}

Field batch testing was performed to determine the dosage of sugar-beet-waste lime required to neutralize each material. Based on these batch tests, the following minimum lime dosages were determined (weight of lime/weight of material):

- Hematite: $52 \mathrm{mg} / \mathrm{g}$

- Jarosite: $274 \mathrm{mg} / \mathrm{g}$

- Disturbed Native: $32 \mathrm{mg} / \mathrm{g}$

- $\quad$ Pit bottom sediments: $78 \mathrm{mg} / \mathrm{g}$

Initial access into the dewatered pit was via an excavated ramp on the east rim of the pit. The ramp was excavated about half-way down to the pit bottom, at which point a temporary fill of lime-treated mine waste and excavation rubble was placed from the bottom of the excavation to the floor of the pit. Prior to beginning excavation of the pit bottom sediments, a large crane with a clamshell bucket was mobilized to remove several vehicles and other debris that were found at the bottom of the pit. After removal of the debris, excavation and treatment of pit bottom sediments began. While excavating the pit bottom sediments, the depth to a hard rock bottom was found to be significantly deeper than originally anticipated. Several test pits were dug into the pit sediments to determine the characteristics and estimate the depth of material in the bottom of the pit. Each test pit exposed a layer of hematite mine waste and/or fill material used for construction of the pit 
ramp, overlying a deposit of non-reactive metavolcanic rubble of undetermined depth. To address the unanticipated thick deposit of rubble on the pit floor, the pit bottom sediments were removed and the upper two feet of coarse rubble material were replaced with a two-foot-thick layer of compacted crushed limestone. The crushed limestone layer provided a base for placing the treated mine waste, and provided buffering for potential migration of acidic water into the pit.

After treatment of the pit bottom sediments, placement of treated mine waste began. A conveyor system was set up for conveying the mine waste and lime into the pit (Fig. 9). The conveyor system consisted of two sets of traps, motors, and conveyors, one for the mine waste and the other for the lime. The two conveyors discharged onto a main conveyor, which transported the mixed mine waste and lime into the pit. A water spray nozzle was located at the end of the main conveyor to minimize dust generation as the material dropped into the pit. The speed of each conveyor was calibrated to obtain the proper lime dosage for each material. The lime and mine waste were further mixed at the bottom of the pit by dozers. The dozers spread the treated mine waste in 8 " to 12 " lifts, and each lift was compacted with a sheepsfoot roller. Treated mine waste was compacted to $95 \%$ of the maximum dry density. Once the elevation of the treated mine waste in the pit approached the elevation of the pit rim, the conveyor system was removed and the mine waste and lime were placed, mixed, and spread in the pit with dump trucks and dozers. Since the volume of material placed in the pit exceeded the capacity of the pit, a mound of treated mine waste was constructed over the pit. After all the treated mine waste was placed, the side slopes of the mine waste pile were armored with riprap to protect the pile from erosion by Little Dry Creek and Dry Creek flood waters.

After the mine waste was excavated, and prior to placement of soil cover, the slopes of the excavated surfaces were regraded locally. The slopes were graded to 3 horizontal to 1 vertical $(3 \mathrm{H}: 1 \mathrm{~V})$ or flatter to reduce erosion, facilitate revegetation, and smoothly merge the topography of the regraded site with the adjacent land. In steep areas, or areas which had an abrupt change in topography, clean fill from a borrow area was placed to flatten the slopes and provide a smooth topographic transition (Fig. 10). 


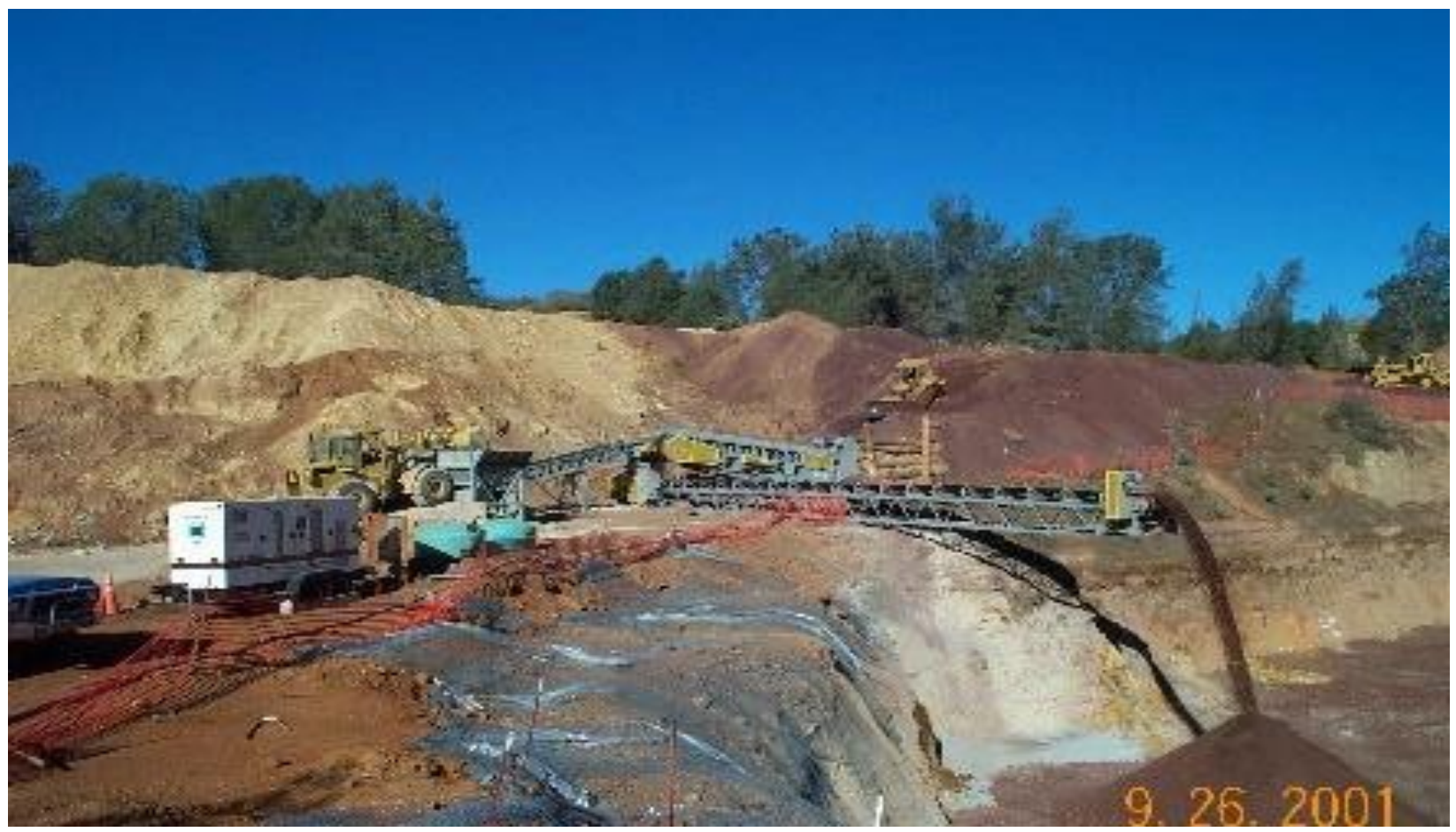

Figure 9. Treated mine waste being placed in the dewatered pit.

\section{Stream Restoration}

Little Dry Creek received run-off leachate from the waste piles and overflow of water from the mine pit, resulting in significant loading of metals and acidic water to the stream. Although the affected area appeared to be mainly restricted to the section of Little Dry Creek adjacent to the mine site, both these factors decreased the suitability of the creek as habitat for aquatic receptors. In addition, Little Dry Creek near the mine site had a hard-bottom substrate of cemented rocks, very little overlying sediment, virtually no submerged aquatic vegetation, and very shallow water in most places. This combination of features contributed to the creek offering poor quality habitat for aquatic species.

Based on a review of pre-mining site photos and a survey of the existing creek bed area, it was determined that the original pre-mining stream channel was east of the existing channel. Stream restoration thus included re-establishing the original stream channel. The construction work involved grading the stream and clearing the old channel before diversion barriers were removed to divert stream flows from the existing channel to the new channel. The altered streambed contains ponds, swales, and large rocks to produce well-aerated water with numerous areas for establishment of pre-mining creek habitat (Fig. 11). Re-colonization by benthic invertebrates from 
upstream locations following re-establishment of normal creek flow should result in re-population of the creek with a similar abundance and diversity of benthic organisms as present before mining occurred.

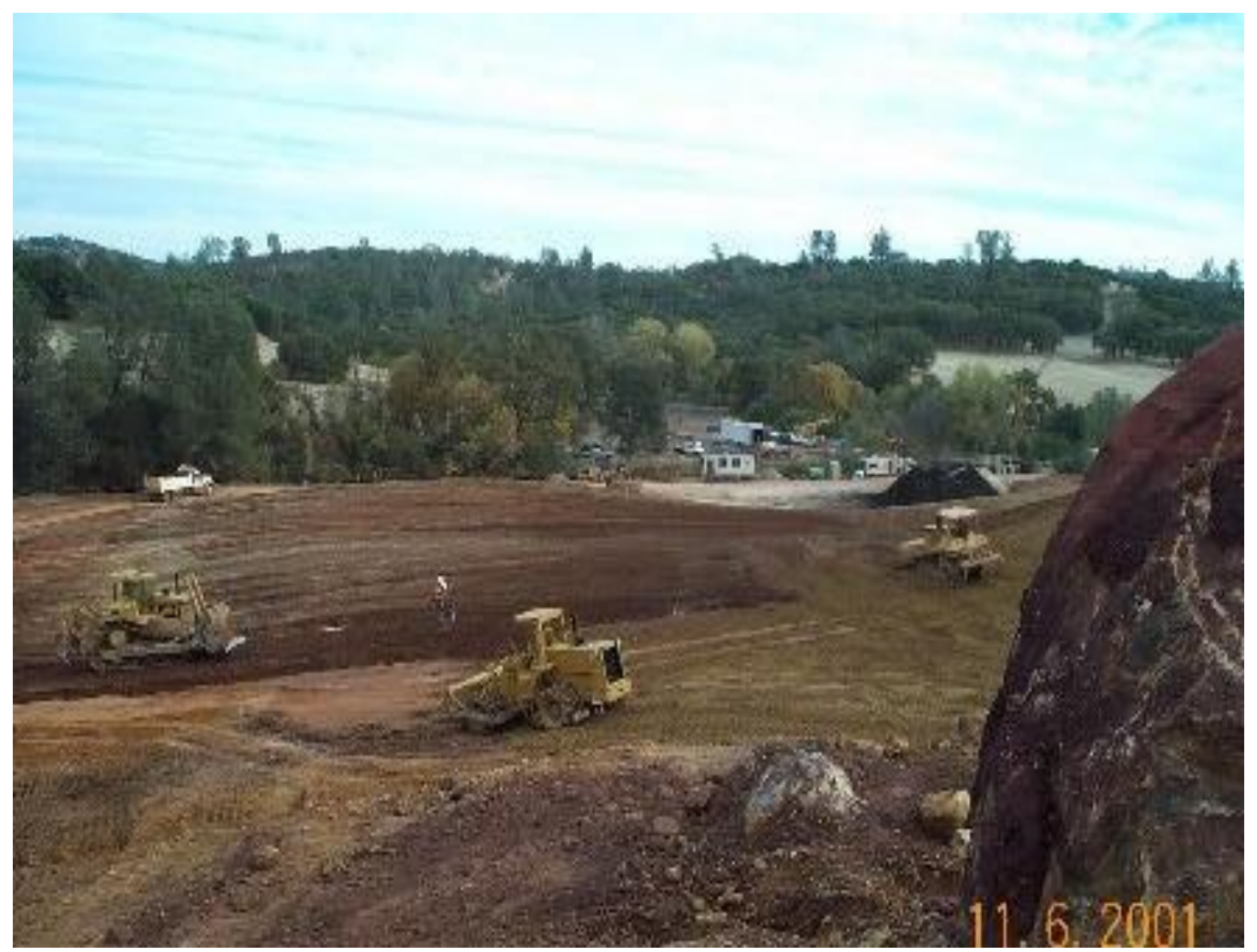

Figure 10. Recontouring the backfilled pit and slopes to pre-mining topography.

Prior to excavation of the new channel, the existing channel of Little Dry Creek adjacent to the mine site was temporarily diverted as part of the remedial work to permit removal of $\mathrm{Fe}(\mathrm{OH})_{3}$ and $\mathrm{Al}(\mathrm{OH})_{3}$ sediments and evaporative salts from the creek bed. Removal was performed by washing the creek bed with high-pressure water jets. After cleaning and excavation of the new channel, the old channel was filled with clean fill and lime rock to ensure neutralization of seeps in the channel and to provide a good growth medium for new vegetation. 


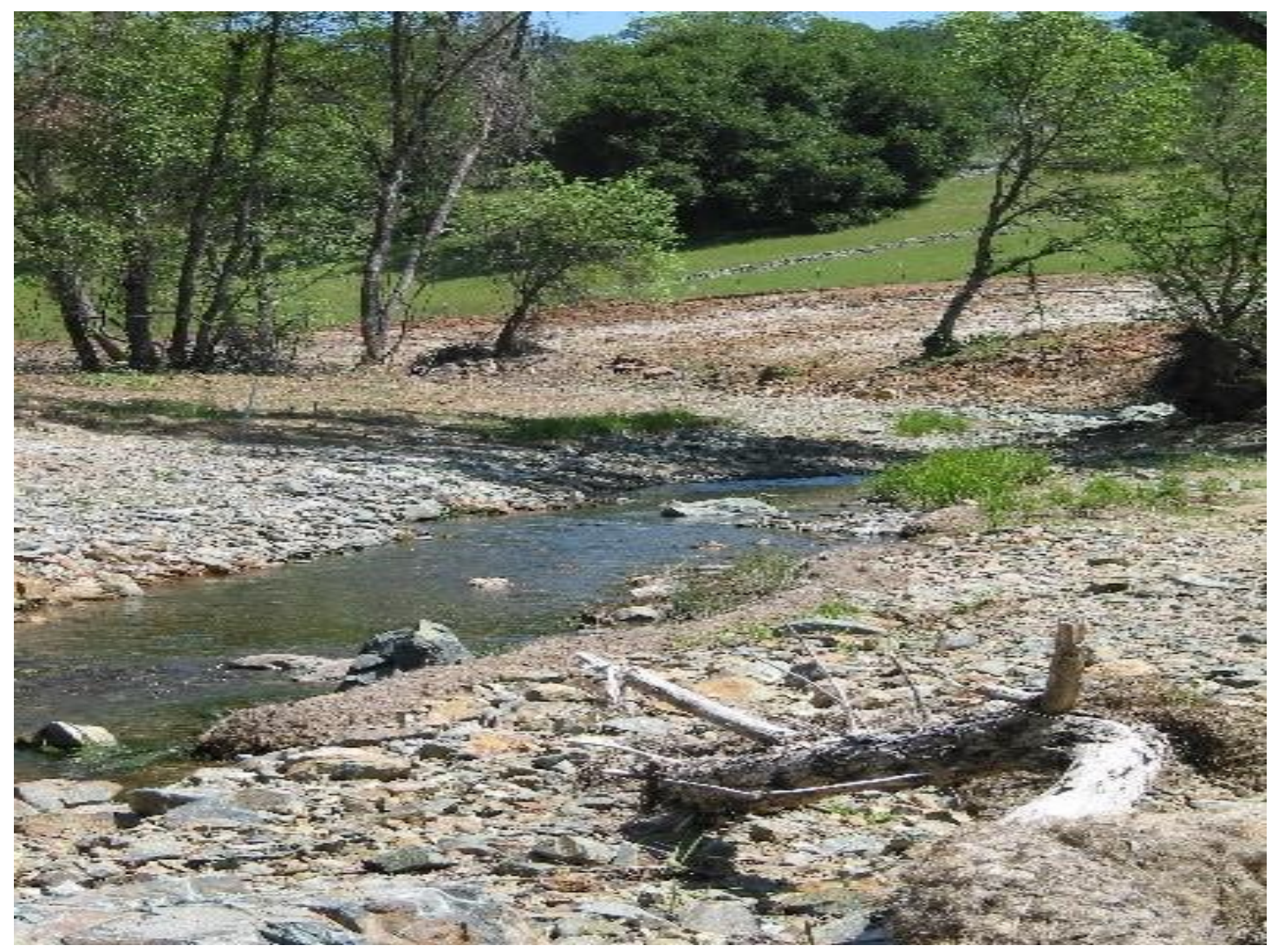

Figure 11. Little Dry Creek re-aligned to pre-mining position.

\section{Site Revegetation}

A revegetation plan was developed to provide a sustainable, erosion-resistant vegetative cover using site-adapted species. Distinct planting zones were created for the relatively steep upper mine slopes, relatively flat lower benches (adjacent to Little Dry Creek), and the graded mine waste pile in order to foster a diversity of plant communities and wildlife habitats throughout the site, and to provide an erosion-resistant vegetative cover in areas with varying slopes, landscape position, etc.

All species were chosen for their adaptability to the site, or for their erosion control or wildlife habitat potential. All native grass and seed used for this project originated from northern California seed accessions. Seeds for the native tree and shrub species were obtained from areas adjacent to the mine site and were grown as containerized seedlings.

\section{Mine Closure Monitoring}

The original long-term monitoring plan was abandoned in 2002 due to a lack of funding within the State of California Agencies. However, monitoring of water quality did occur for several 
events over the last 15 years along with general observations on the stream habitat and site revegetation.

Water in Little Dry Creek and in a shallow groundwater from a well downgradient of the now back-filled pit were sampled and analyzed in 2002, 2007, and 2013. Table 3 presents the surface water chemistry in Little Dry Creek and Table 4 presents the shallow groundwater analyses.

Table 3. Surface water chemistry in Little Dry Creek
$\begin{array}{cccccc}\text { Year } & \text { Month } & \text { pH } & \text { Cu (mg/L) } & \text { Fe (mg/L) } & \text { Zn (mg/L) } \\ \mathbf{2 0 0 2} & \text { October } & 4.1 & 28 & 115 & 17.5 \\ \mathbf{2 0 0 7} & \text { November } & 7.1 & 1.37 & 16.3 & 2.54 \\ \mathbf{2 0 1 3} & \text { August } & 7.3 & 0.35 & 1.63 & 1.17\end{array}$

\begin{tabular}{|c|c|c|c|c|c|}
\hline Year & Month & $\mathrm{pH}$ & $\mathrm{Cu}(\mathrm{mg} / \mathrm{L})$ & $\mathrm{Fe}(\mathrm{mg} / \mathrm{L})$ & $\mathrm{Zn}(\mathrm{mg} / \mathrm{L})$ \\
\hline 2002 & October & 3.3 & 21 & 2877 & 26 \\
\hline 2007 & November & 5.9 & 2.13 & 111 & 4.13 \\
\hline 2013 & August & 6.7 & 0.86 & 22.4 & 2.77 \\
\hline \multicolumn{2}{|c|}{ Water Quality Objective } & 7.5 & 0.2 & $<10$ & 2 \\
\hline
\end{tabular}

Surface water chemistry improved markedly during the first 5 years of post-closure. The $\mathrm{pH}$ increased from 4.1 to 7.1 and then 7.3 in 2013. Copper concentrations decreased from $21 \mathrm{mg} / \mathrm{L}$ to $2.1 \mathrm{mg} / \mathrm{L}$ in 2007 and $0.35 \mathrm{mg} / \mathrm{L}$ in 2013. Iron concentrations decreased from $2,877 \mathrm{mg} / \mathrm{L}$ to 1.63 $\mathrm{mg} / \mathrm{L}$ in 2013, while $\mathrm{Zn}$ concentrations decreased from $17.5 \mathrm{mg} / \mathrm{L}$ to $1.17 \mathrm{mg} / \mathrm{L}$ in 2013 . However, the decrease in $\mathrm{Cu}$ concentrations is still higher than the water quality goal of $0.2 \mathrm{mg} / \mathrm{L}$. Continued monitoring will be conducted assuming availability of funding and personnel.

Groundwater chemistry (Table 4) is similar to the surface water chemistry (Table 3) with notable differences. For example, $\mathrm{pH}$ of the groundwater increased from a low of 3.1 in 2002 to about 6.7 in 2013 exhibiting a much slower recovery to near neutral conditions when compared to surface water chemistry. Iron concentrations decreased only to $22 \mathrm{mg} / \mathrm{L}$ in 2013 , an order of magnitude higher than the surface water chemistry iron concentrations. The slower reduction in concentration is probably related to the groundwater flow velocity and path although no reliable 
measurements of either have been made. As with the surface water chemistry, continued monitoring would be advantageous for defining the long-term success of the project.

The site revegetation probably suffered the most when the monitoring plan was abandoned. There were plans for assessing the density and distribution of different plant species, determination of the native plant success versus the amount of invasive species, and overall above ground vegetative health especially given the very dry conditions that have persisted in California for the last decade. At best a pictorial library has been kept of which the three figures below are characteristic. Figure 12 shows the site at the very completion of the closure while Figs. 13 and 14 show the site in 2006 and 2011, respectively. For reference the tailings pile in the upper left of Fig. 12 is also shown on the other figures as a contoured slope in the same location.

While not particularly quantitative, the photographs give the general impression that the restoration of the site was generally successful. In 2013 and more recently in 2015, several burn areas along the side slopes of the former tailings piles were noted. There are plans to improve the cover in these areas in the fall of 2016.

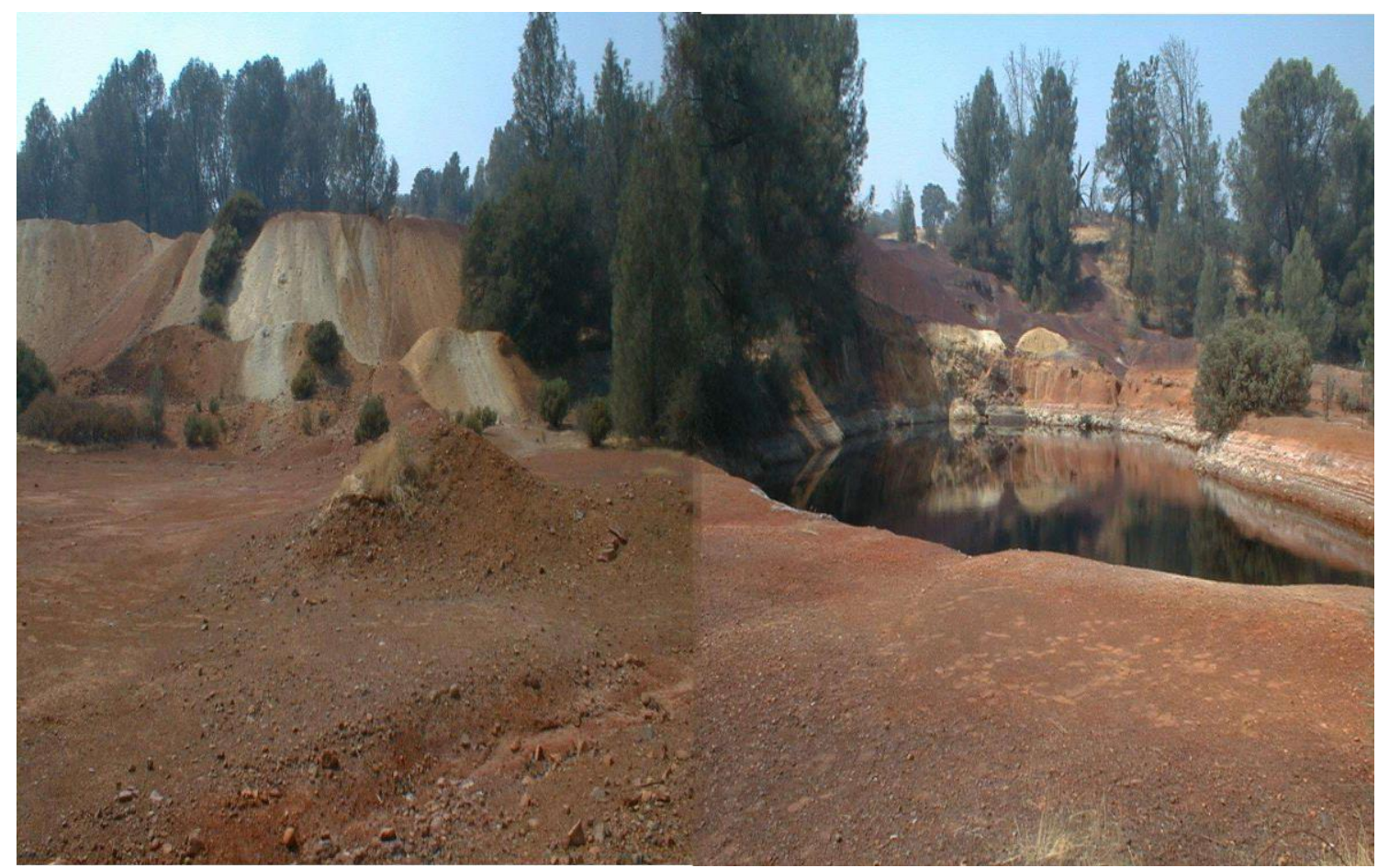

Figure 12. Final mine property contour, former pit is in the center of the photo (2000). 
JASMR, 2016 Volume 5 Issue 1

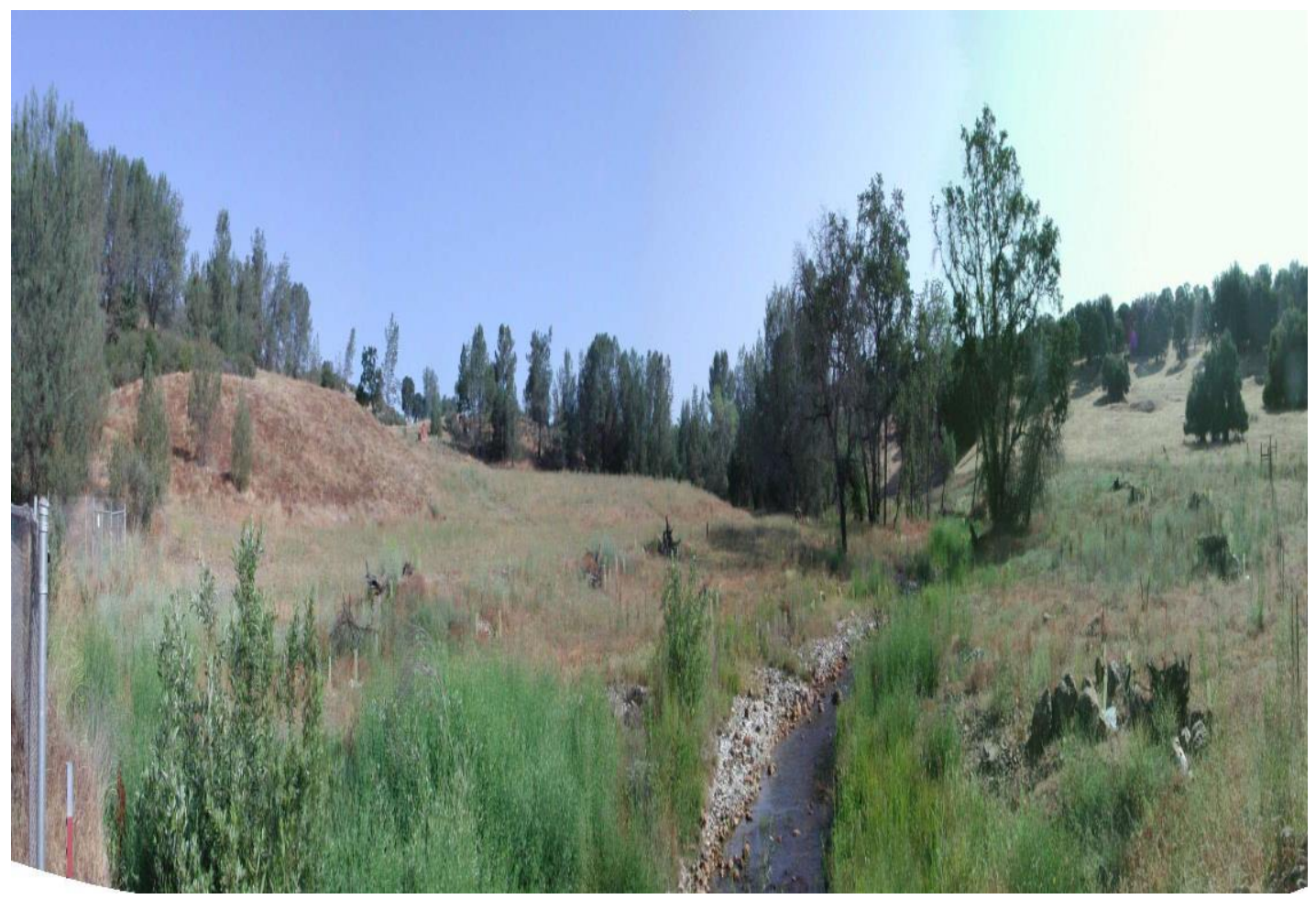

Figure 13. Mine site as of March 2006

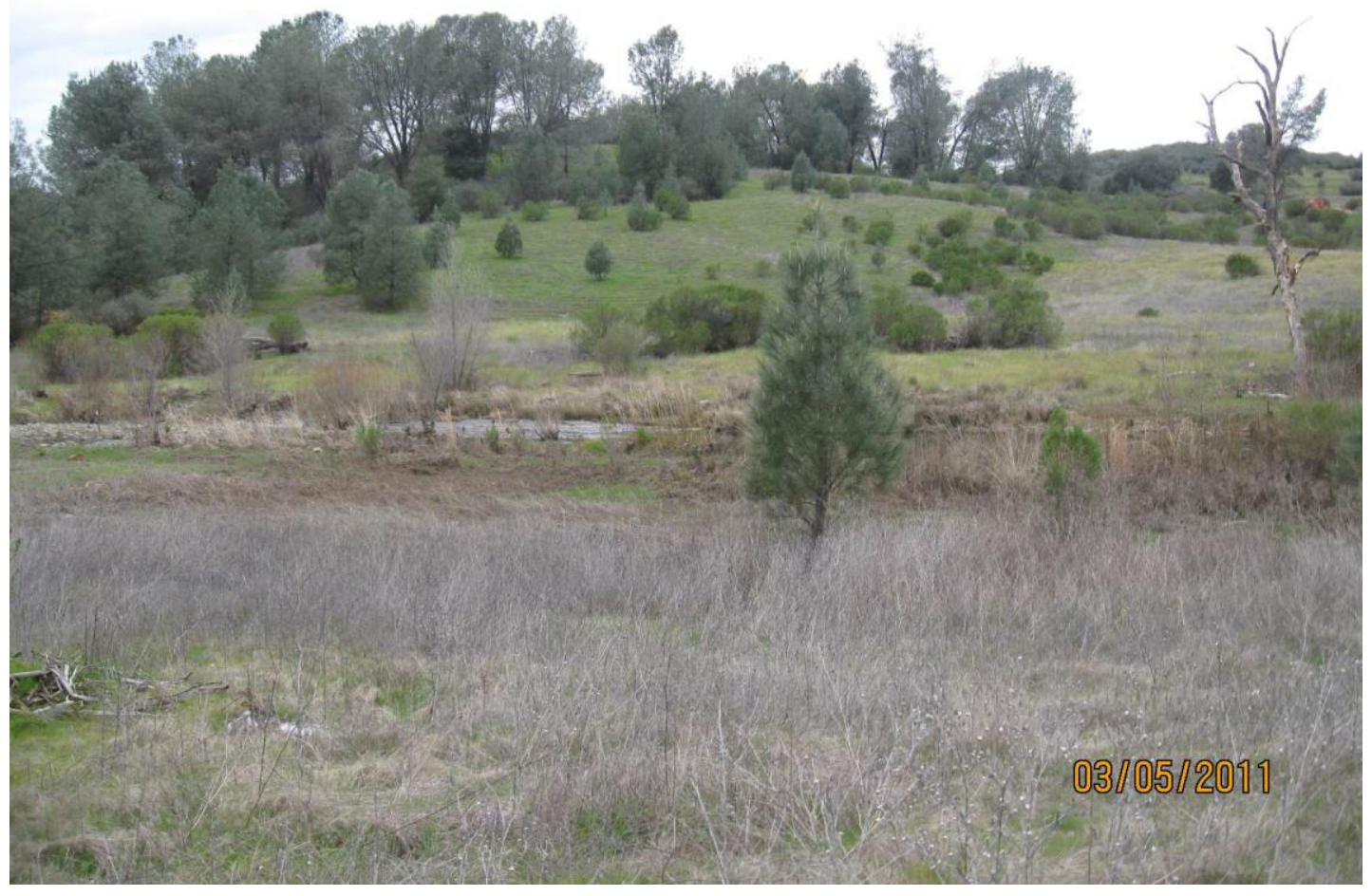

Figure 14. Mine site as of 2011. 


\section{SUMMARY}

The Spenceville Mine Closure proceeded on schedule and was essentially completed in 18 months. Additional revegetation was accomplished within an extra 3 months. The closure accomplished the following items:

- The mine pit was drained in 11 weeks and treated water was used to irrigate nearby fields.

- The pit was backfilled with neutralized mine waste and then covered with clean fill. The shafts and adits were also packed with lime rock and then filled with treated waste rock to minimize seepage.

- The site was contoured to fit pre-mining contours and much of the area has already been revegetated.

- The nearby stream, Little Dry Creek, was moved to its original location and stream habitat restored. Seeps and overflow from the flooded mine pit were eliminated.

- Intensive archaeological studies unearthed old mining structures and sites of cultural interest that were catalogued and preserved for future access.

- Surface water and groundwater have been restored to near pre-mining conditions. Both will be monitored into the future depending on funding sources.

- The Spenceville Mine site has been returned to usable open space consistent with the intent of the wildlife refuge.

\section{ACKNOWLEDGMENTS}

The authors would like to recognize the following individuals who played key roles in the success of this project: Steve Reynolds, Depertment of Fish and Game; Kit Custis, CA Mines and Geology; Ron Peery, Rick Gunderson, and Eric Mason, CRE Construction; and Ian St. James, Lara Pucik Johnson, and John "Spike” Palmer Walker and Associates,.

\section{REFERENCES}

Walker and Associates and GEI Consultants, Inc., July 2000, Mine Site Characterization/Closure Plan, Spenceville Mine Site, Nevada County, California.

Wanket, 2002. The Spenceville Mine Closure Summary Document, GEI Consultants, Oakland CA.

Walker, W.J. 2003. The Spenceville Mine Closure - Technical Approach to Mine Dewatering, Water Treatment and Water Re-Use for Irrigation. California Department of Fish and Game. Sacramento, CA. 